\title{
Erratum to: Molecular detection and identification of piroplasms in sika deer (Cervus nippon) from Jilin Province, China
}

Junlong Liu ${ }^{1,2^{*}}$, Jifei Yang ${ }^{1,2}$, Guiquan Guan ${ }^{1,2}$, Aihong Liu ${ }^{1,2}$, Bingjie Wang ${ }^{1,2}$, Jianxun Luo ${ }^{1,2}$ and Hong Yin ${ }^{1,2}$

\section{Erratum}

Unfortunately, the original version of this article [1] contained an error. Within the results section, and in Fig. 1, the accession numbers KT683524-KT683536 should be KT863524-KT863536. The correct version of Fig. 1 can be found below.

We would like to apologize for this error and for any inconvenience this may have caused.

Received: 23 March 2016 Accepted: 23 March 2016

Published online: 01 April 2016

\section{Reference}

1. Liu J, Yang J, Guan G, Liu A, Wang B, Luo J, et al. Molecular detection and identification of piroplasms in sika deer (Cervus nippon) from Jilin Province, China. Parasite Vector. 2016;9:156. doi:10.1186/s13071-016-1435-3.

\footnotetext{
* Correspondence: liujunlong@caas.cn

${ }^{1}$ State Key Laboratory of Veterinary Etiological Biology, Key Laboratory of Veterinary Parasitology of Gansu Province, Lanzhou Veterinary Research Institute, Chinese Academy of Agricultural Science, Xujiaping 1, Lanzhou, Gansu 730046, P. R. China

${ }^{2}$ Jiangsu Co-innovation Center for Prevention and Control of Important Animal Infectious Diseases and Zoonoses, Yangzhou 225009, P. R. China

Submit your next manuscript to BioMed Central and we will help you at every step:

- We accept pre-submission inquiries

- Our selector tool helps you to find the most relevant journal

- We provide round the clock customer support

- Convenient online submission

- Thorough peer review

- Inclusion in PubMed and all major indexing services

- Maximum visibility for your research

Submit your manuscript at

www.biomedcentral.com/submit 


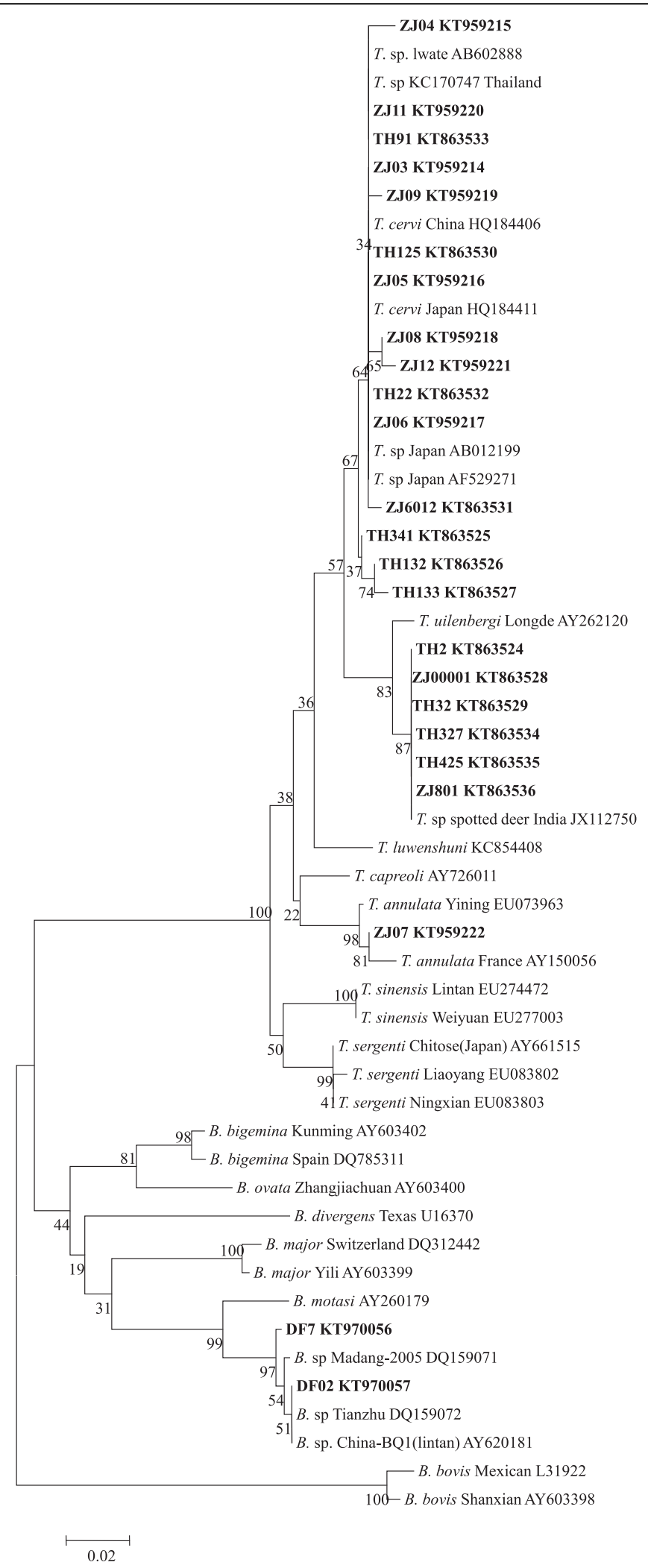

Fig. 1 Phylogenetic tree of Theileria and Babesia spp. based on the V4 region of $18 \mathrm{~S}$ rRNA gene sequences. The parasite identified in the present study is marked in bold 